\title{
Fields, Funerals and Furnaces \\ On the Use of Fire during the Pre-Roman Iron Age on the Island of Gotland
}

\author{
Anna Arnberg
}

\begin{abstract}
By studying the material culture of the island of Gotland, one can conclude that the use of fire was integrated into the lives of the Pre-Roman people. Agricultural land was cleared by fire and cremation was a part of the burial tradition. Fire converted clay into ceramics, wood into charcoal and bog ore into iron. By being subjected to the flames human beings, objects and the landscape were created and/or transformed. This paper presents fossilized field systems, burial grounds and areas with iron production as places for this physical transformation, as well as places for the creation of bonds between people.
\end{abstract}

Anna Arnberg, Department of Archaeology, Stockholm University, SE10691 Stockholm, Sweden.

Key words: Fire, earth, agriculture, burial traditions, iron production, PreRoman Iron Age, Gotland, Kräklingbo parish, Stånga parish.

The nature of fire is ephemeral. When deprived of fuel the flame goes out. Fire is thus dependant for its existence on other materials and can, archaeologically, be studied only in relation to its various material effects (Gheorghiu 2002:1). Besides, the effects of the flames are multilateral. Fire is partly the destroyer, associated with disaster, partly the preserver, making other materials imperishable and thus available to us to study, and partly the transformer. In relation to the Pre-Roman Iron Age on Gotland, the flames converted clay into ceramics, wood into charcoal, bog ore into iron, etc. The use of fire was also a contributing factor in the shaping of the Pre-Roman landscape. Agricultural land was cleared by fire and cremation was a part of the burial tradition. Through these, and a number of accompanying activities, the surroundings were slowly transformed. This paper presents fossilized field systems, burial grounds and areas with iron production as physical places for this transformation. Examples are taken mainly from localities in Kräklingbo and Stånga, two parishes on the island of Gotland. The discussion focuses on the altering character of fire in relation to the human body, objects and landscape, as well as on agriculture and burial traditions as activities connecting people. 


\section{KRÄKLINGBO PARISH: THE FOREST FIRE AND THE FOLLOWING SURVEY}

For some days in July 1992, the forests in the eastern parts of Kräklingbo parish and the western parts of Gammelgarn parish were on fire. On Thursday the $9^{\text {th }}$, when the media started reporting these fires, there was a fresh breeze coming from the south-west and the fire spread rapidly from its starting-point by the hillfort of Torsburgen over an area of 20 square kilometres (Fig. 2). Despite the enormous efforts of fire-fighters, military personnel and volunteers, it was not until three days later that the flames were brought under control, and it was a few days after that before the fire was completely extinguished (Fig. 1). It was now confirmed that vast areas had been heavily scorched, occasionally to such a degree that the covering soil had disappeared, displaying the white limestone bedrock (Carlsson 1992, 1993:17; Johansson 1993:2; Lindquist 1993:7; Östergren 1992:44).

Rather miraculously, no people were injured and no houses were damaged by the fire (Östergren 1992:44). Though the fate of the woodlands was not as benign, the emotional and economic disasters were nevertheless severe (Eliason 1993:11). As it was feared that the ancient remains might have suffered the same fate, a survey was planned. Aiming to make use of the preferable conditions for spotting features formerly hidden by vegetation, it was conducted as soon as the flames had been put out (Östergren 1992; Carlsson 1992, 1993). It was concentrated to the fire lines and the surveyors concluded that 40 ancient remains showed firerelated damage, a number much lower than expected. It was also discovered that only a few localities, amongst them a burial ground from the Pre-Roman Iron Age, were so badly damaged that rescue excavations had to be carried out (Carlsson 1993:17; Zerpe 1999; Östergren 1992:45).

\section{THE FOSSILIZED FIELDS OF KRÄKLINGBO}

The survey confirmed the enormous power of the flames and their ability to

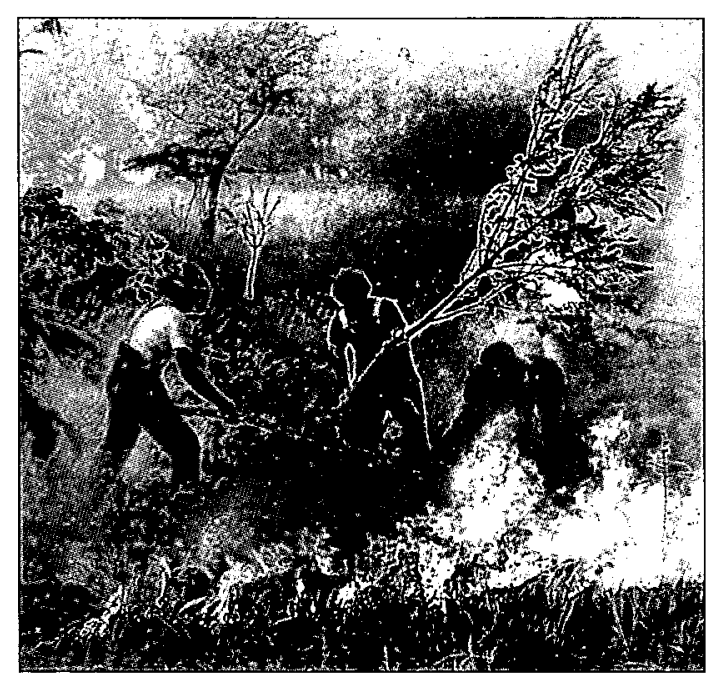
transform the landscape. The area south of the farm of Ekeskogs, about 1,5 kilometres south-east of the church of Kräklingbo, was covered with pine trees before the fire (Fig. 2 ). Now however, large parts of the forest were wiped out and the covering soil reduced to a thickness of between 5 and $20 \mathrm{~cm}$ (Johansson 1993:13). Before 1992, only a few stone walls (Sw. stenvallar),

Fig. 1. Conscripts fighting the forest fire in Kräklingbo. Photograph by Ulf Glimfalk (Lindquist 1993:10). 


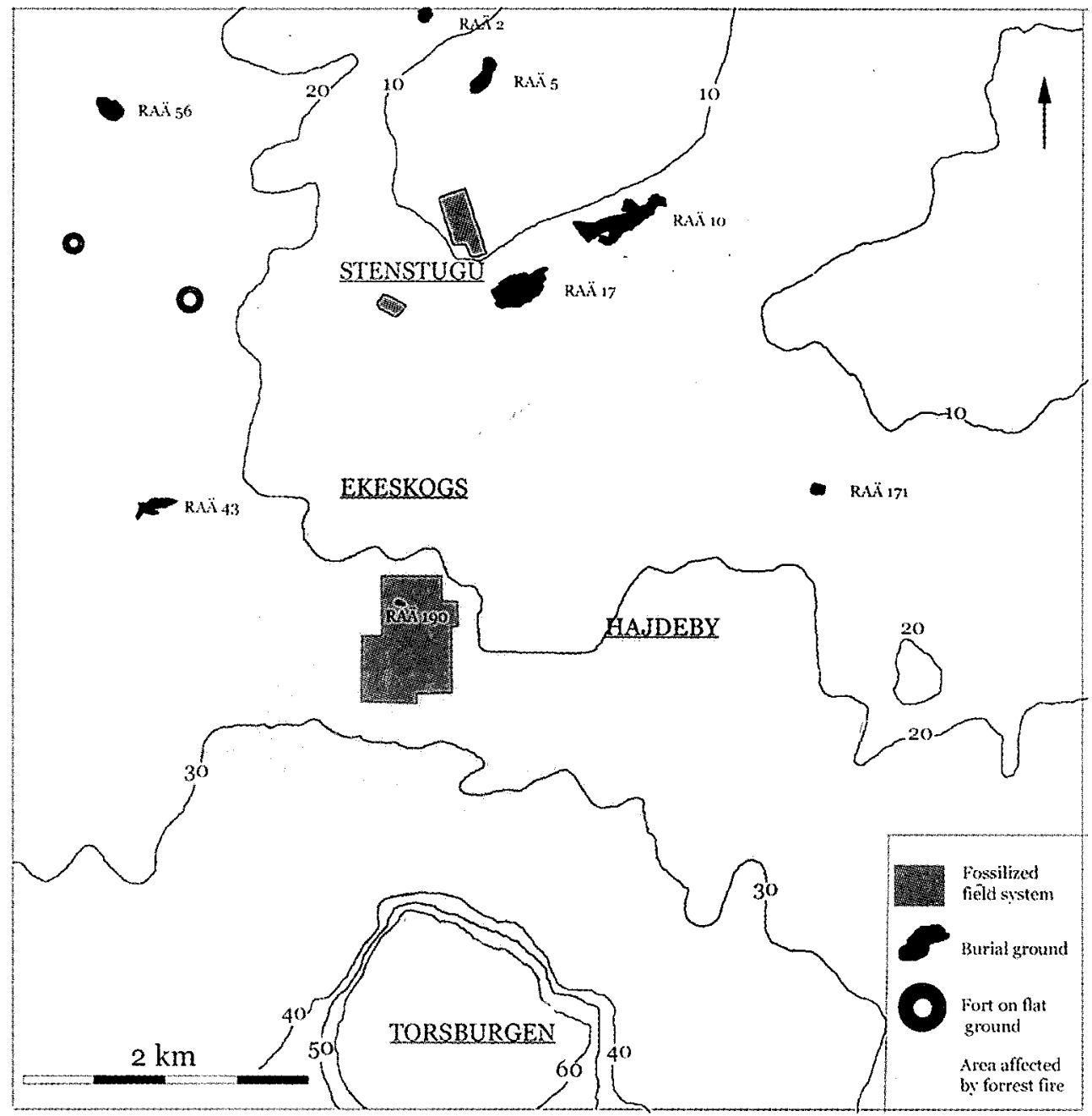

Fig. 2. Kräklingbo parish with the area affected by the forest fire and the localities mentioned in the text mapped out. Based on FMIS, Carlsson 1979 and 1992.

a couple of stone enclosures (Sw. stensträngar) and some graves were known in this barren area, but in the burnt ground a fossilized landscape with an extent only surpassed by a few localities on the island made its appearance (Carlsson 1993:19).

The area was mapped by Stefan Johansson and published in the form of an essay (Johansson 1993) (Fig. 3). The newly discovered remains comprised mostly graves, stone enclosures, clearance cairns and field plots surrounded by baulks of stones or soil (Johansson 1993:13ff). Plots surrounded by stone baulks have been detected at other Gotlandic localities as well (Johansson 1993:16ff; Carlsson 1979:123; Manneke 1974:35), but compared with other agricultural remains, have been paid little attention, as regards both dating issues and excavations. A 


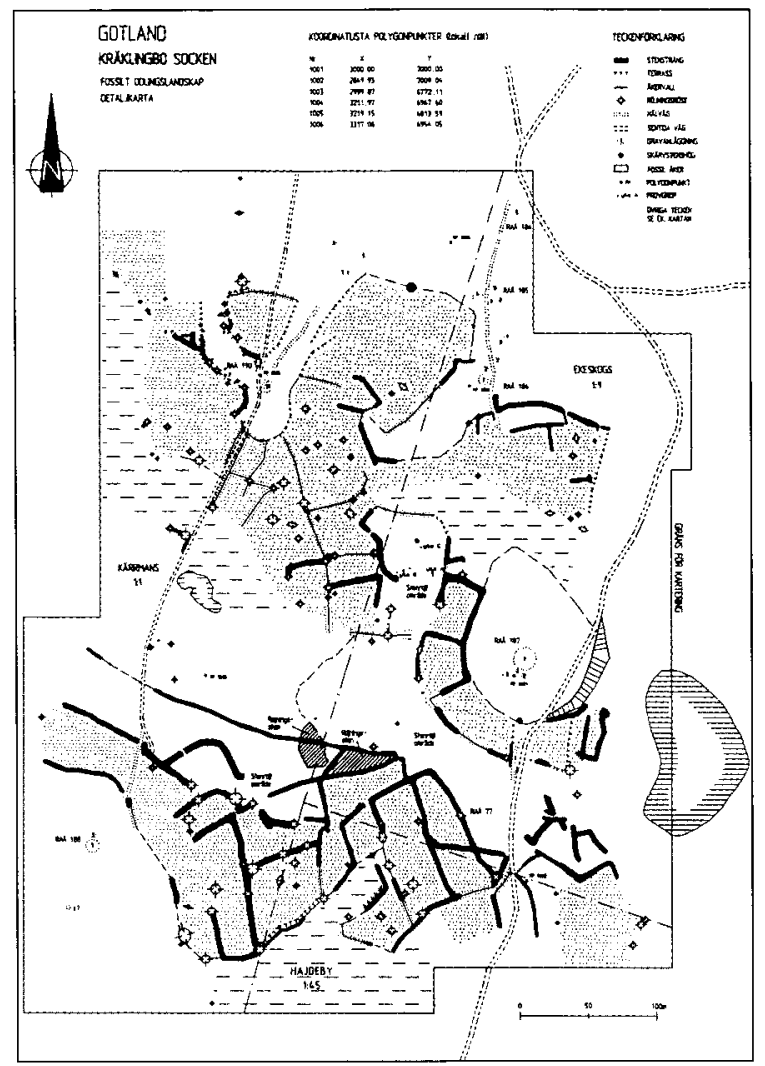

Fig. 3. Map of the fossilized landscape south of the farm of Ekeskogs in Kräklingbo parish (Johansson 1993:14).

chronological discussion regarding the stone-baulked plots at Ekeskogs thus has to be based on other criteria, such as (1) the spatial relation to other remains, for example a cairn, a ship-setting and stone settings, (2) the stratigraphical relations within the locality, where clearance cairns had in several cases been incorporated in the field walls (Johansson 1993:29), and (3) the chronological positioning of similar field systems outside the island of Gotland.

In the early $1990 \mathrm{~s}$, Valter Lang visited this cultivation area in Kräklingbo and stressed its similarity to excavated, fossilized, field systems in Estonia, by him called Baltic fields. Construction details in combination with obtained ${ }^{14} \mathrm{C}$ values, led him to the following conclusion, a conclusion, he argues, that is applicable to the Gotlandic fields as well. He emphasizes that the field systems, as well as the baulks of the single plots, were formed stepwise, the latter through the interconnection of some of the clearance cairns (Lang 1994:214f). Regarding the chronological relation between clearance cairns and stone baulks, he sees this as a short process: "(the) first baulks were formed very soon after the beginning of clearance and heaping up of the first cairns" (Lang 1994:215). The ${ }^{14} \mathrm{C}$ dates indicate that the agricultural remains originated from the Late Bronze Age and Early Pre-Roman times (Lang 1994:211). In addition, these Estonian, stone-baulked fields providing a similar dating have been excavated in the province of Östergötland (Ericsson 2000a:24).

Besides stone-baulked plots, the north-eastern part of the cultivation area at Ekeskogs contains some plots of the type that are commonly associated with Gotland, i.e. where the field limits consists mostly of soil (cf. Carlsson 1979:49f). Similar fields, often referred to as Celtic fields, have also been found in Stenstugu, about 1,5 km north of Ekeskogs (Fig. 2). Here two separate systems of altogether 6 hectares, have been detected. These were flanked by modern fields and might therefore originally have been larger (Carlsson 1979:113ff). The area on Gotland 
most intensely investigated regarding this kind of agricultural feature, is UggårdeVinarve in the parish of Rone, where excavations started in 1973 (Lindquist 1974:6). After the topsoil had been removed, criss-crossing ard-marks were displayed in the light subsoil. In connection with these marks, charcoal was found in such large amounts that it was presumed to derive from the clearance of the plot (Lindquist 1974:17). The ${ }^{14} \mathrm{C}$ values indicated that field systems were in use at least from the Late Bronze Age to the Roman Iron Age. The use of fire during prehistoric times hence became the key to an absolute dating for fields with earthen ridges. The ${ }^{14} \mathrm{C}$ values also indicated that the majority of the plots were not in use at the same time. The vast areas of conjoined plots should instead be looked upon as the result of a successive growth, created over a long period of time (Windelhed 1984a:184; for the dating of other localities see Carlsson 1979 and Spek et al. 2003).

\section{MATERIAL EXPRESSION AND AGRICULTURAL PRACTICE}

As regards the construction material, the field walls bear witness to a somewhat different cultivating practice. The earthen ridges have come into being as the result of the ard slowly depriving the plot of its fertile topsoil and repositioning it on the edges (Windelhed 1984a, 1984b), while the stone baulks are the result of the use of the ard in combination with the putting up of stone (Lang 1994). The consequence is a partly different material expression, caused by a partly different practice. On Gotland, in Estonia and in Östergötland as well, these dissimilarities seem to be correlated with different geological conditions. Stone-baulked fields are mainly located on moraine heights or on alvar (Carlsson 1993:19; Ericsson 2000a:24; Lang 1994:203, 212; Manneke 1974:35), while the earthen-ridged fields are located on sandy or clayey soils (Carlsson 1979:49f). The creation of often quadrilateral plots joined together in a web-like system, is however similar. The same goes for many of the tasks leading forward to these expressions.

Returning to Kräklingbo parish, it is likely that the fossilized field systems of Ekeskogs and Stenstugu are mainly contemporaneous phenomena, having grown larger side by side. In both cases, the webs of conjoined plots are the result of a chronologically extended process. The picture has grown out of sequences of interlinked tasks carried out in a similar way over the centuries. Time after time the ecological conditions were transformed in order to create a better setting for other types of growth. Fire and tools cleared the chosen spot, and stones were carried away. The soil was then ploughed, the crop sown and harvested and the corn was ground. Some years later, the plot lay fallow (Carlsson 1979:154; Lindquist 1974:29; Windelhed 1984b:97). New plots were used, while the resting or abandoned ones might have been used for other purposes such as pasture, housing or different types of crafts.

\section{THE CREATION OF A LANDSCAPE BY FIRE AND LABOUR}

The charcoal from field clearance might in relation to the single plot be regarded 
as a starting-point. Taking all plots into consideration, the ${ }^{14} \mathrm{C}$ values indicate that the use of fire was a recurrent element in the agricultural practice, an element that in favourable cases increased the productivity but that also meant taking a risk. Being able to control the fire was crucial, partly because it could spread and partly because in its uncontrolled form it could destroy fertile soil (cf. Gren 1995:94). The latter was shown not least in the aftermath of the fire of 1992 (cf. Johansson 1993:13). The nature of the element is complex; it is the destroyer but also the creator granting new life.

Clearance by fire was, however, not the only task, and probably not the most important, leading up to these material expressions. Fire has been used for agricultural purposes from Neolithic to historical times (Myrdal 1995), in many cases without leaving such physical traces. Essential for the visibility and extension of the Gotlandic field systems were instead the use of the ard, accompanied by various activities that prolonged the use of the single plot. The plots being used longer meant that they were ploughed at more times, allowing the baulks, whether of stones or of soil, to grow higher and wider and because of that more visible in relation to the surrounding landscape (cf. Windelhed 1984a, 1984b). As for Gotland, it has been suggested that the re-use of the single plots was based on fallow periods, possibly in combination with the spreading out of household refuse (Carlsson 1979:154; Lindquist 1974:29). For Hugelsta in the province of Södermanland, Alf Ericsson has suggested another form of fertilizing. Through chemical analyses of the soil, he has come to the conclusion that ashes ( $\mathrm{Sw}$. vedaska), probably deriving from hearths excavated near by, had been spread over the fields prolonging their period of use (Ericsson 2000b:33f). Hearths in connection with fields are, however, not a phenomenon unique to Södermanland. As for Gotland, scattered hearths are not unusual at agricultural localities (Carlsson 1979:84). In other words, there is a possibility that the use of fire was not limited to the creation of a plot but should be regarded as an integrated and constantly recurrent part of the agrarian process.

\section{AGRICULTURE AS A SOCIAL ACT CONNECTING PEOPLE}

Food production may be regarded as the prime purpose of agriculture, but in a Pre-Roman perspective tillage also had social and material consequences. When involved in the act of cultivation, people obtained a role in relation to the surrounding society. Though many tasks could theoretically have been carried out by one individual, the chain from clearing the fields to putting food on the table often involved several persons, persons in different ways connected with each other (cf. Ingold 2000:207). People lived together, ate together and cultivated the land together. In this perspective, tillage may be regarded as a medium for the creation of relations between people and the fields as physical places for this creative act.

The field systems, as they are visible today, are the result of a process in time. The procedure stayed more or less same for up to a thousand years or longer (cf. 
Windelhed 1984a:184). As a consequence, cultivation was not the concern of one generation solely, but an act linking generations together. Working side by side with the older members, the tradition was handed on to the younger members of society. Hence, knowledge has in this context as much to do with conversations and with people's bodily engagements with the world, as with abstract thought (cf. Ingold 2000:189; Thomas 1996:19). As the place for labour, the fields were the arenas where the youth were taught how to carry out the tasks involved in a proper manner. As an arena for communication, the fields might also have been the place where they learned why land was worked in this way and perhaps also where they heard stories of the nature of this world and of people's places in it. The knowledge, completed in the progression of agricultural techniques, gained by repeatedly being handed on to the next generation, in physical form. In the field systems the acts carried out were materialized, acts that over the centuries had involved numbers of people.

Because the ard deprived the plot of its soil, areas formerly used for cultivation were eventually transformed into infertile land (Windelhed 1984a, 1984b:97). From a modern Swedish point of view, in which few words in combination with agriculture sound better than "ecological", the effects of the ploughing would probably best be described as destroying natural resources. But the question is, how did the cultivators perceive their destruction of arable land? Presumably not in such negative terms. For though some steps were taken to prolong the fertility plot, a fact that may indicate that the effects were in some way alleged to be problematic, this did not stop people acting upon the land in this way. To my mind, traditions like this one do last, not because people are unable to carry out tasks in other ways, but because traditions offer something to the people maintaining them (cf. Bradley 2002:11). The values that agriculture offered the PreRoman people, besides providing them with food, might partly be explained as involving them in a historically established process. It was a way of maintaining land that as phenomenon and material expression reached beyond the individual and the individual's lifetime. In other words, this tradition did not just connect people in a contemporary perspective. In the landscape of conjoined plots, relations between people, between present and past and between people and place attained physical form. Through the continuance of the agrarian techniques, the cultivator was literally woven into these materialized relations, at the same time as these cross-generational connections were preserved. What with the ideals of $21^{\text {st }}$ century was described as a destruction of fertile land might with these associations instead have been perceived as something attractive and desirable. Perhaps it was these associations that "justified" the waste of productive land.

\section{PRE-ROMAN BURIAL TRADITIONS: A TRANSFORMATION OF THE HUMAN BODY AND THE LANDSCAPE}

Since the early days of archaeology, a large number of graves and burial grounds dating from the Pre-Roman Iron Age have been excavated, the great majority of 
them cremation graves. As for Gotland, great efforts have been made to establish a local chronology for artefacts and graves, providing favourable conditions for future archaeological research (see Nylén 1955, 1958a). Mortuary practices are, however, complex phenomena and can be perceived and interpreted in different ways, both from a prehistoric and a contemporary point of view. The latter is shown not least by the copious archaeological literature dealing with this subject. The theoretical perspectives have varied and the interpretations too, a fact that to some extent can be related to the author and his or her time but that may also reflect the fact that burial traditions from a prehistoric point of view are also complex phenomena constituted by a number of interwoven elements. Archaeological studies have focused on the symbolic meanings of these elements, on the deceased and his or her position in society, on the relation between the deceased and the living, on the society that the deceased was a part of, on notions of life and death. The examples can be multiplied. Here the focus will be partly on the transforming character of fire in relation to the human body and the landscape and partly on mortuary practices and burial grounds as phenomena connecting people.

When taking up fire lines in trying to control the forest fire at Kräklingbo, a burial ground dating from the Pre-Roman Iron Age was severely damaged (Zerpe 1999:23) (Fig. 4). This burial ground (RÄ̈ 171), located on the estate designated Hajdeby 1:38, has together with six others, been mapped out in Fig. 2. Few graves on the latter have been excavated, but they all contain grave forms characteristic of the Pre-Roman Iron Age (see Nylén 1958a). The burial ground of Hajdeby comprised nine graves, all containing cremation burials. In most cases, the fragmented and burnt bones had been spread on the natural ground before they were covered with earth and stones (Zerpe 1999:13, 23). In one case, though, the bones might have been put in a centrally placed cist of limestone slabs (Zerpe 1999:27). As was common during the Pre-Roman Iron Age, the artefacts were mainly accessories originating from the dress of the deceased. Besides being marked by fire, these Gotlandic accessories often show traces of wearing and hence had probably been worn during life as well. Interestingly enough, we often have the fire-induced patina to thank for the iron objects being well preserved, as it protects them from corrosion (Nylén 1958b:3f). Thus, also in this case, the

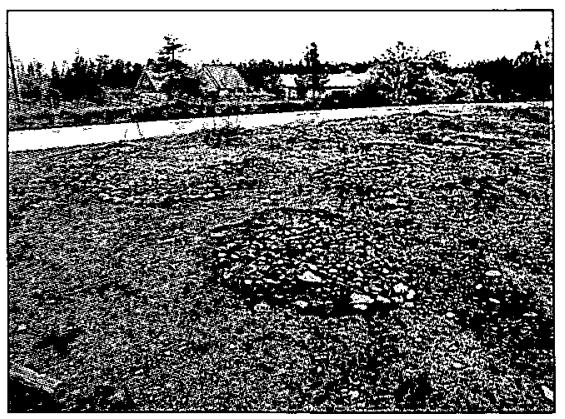
prehistoric peoples' use of fire has improved the conditions for archaeological research.

Burial grounds like this one are the result of repeated activities performed over a long period of time. A burial ground thus embodies the acts of the living as much as the dead. The graves at Hajdeby show great

Fig. 4. The burial ground at Hajdeby 1:38, RÄ̈ 17I, ATA. 
similarities between themselves. A fair assumption is therefore that several of the activities that surrounded the burials were conducted in a similar way. Since all of them are cremation graves, the gathering of wood and the piling up of the pyre must have been recurrent tasks in this process. When they were performed, the deceased was placed on the pyre and the fire was lit. On being subjected to the flames, the human body now disintegrated. During the Late Bronze Age and Early Iron Age, this physical disintegration sometimes seems to have been accompanied by the deliberate crushing of the bones (Kaliff 1997:87). Later, when the pyre had burned out, the debris was assembled and parts of it spread on the ground or placed in a small stone cist. Finally, the remains were covered with stones and soil.

During the excavations at Hajdeby, it was noticed that the ground under one of the stone settings was scorched, a phenomenon not detectable under the others. Besides being burnt, the area contained fire-scarred and pulverized stones. The report indicates that these might have been the traces of a funeral pyre (Zerpe 1999:14). It is, however, from the published sections difficult to evaluate these traces (Zerpe 1999, Fig. 7), and therefore hard to estimate the probability of this suggestion. It has in other contexts been suggested that fire may have been used as an initiation ritual to prepare and mark a specially selected place (Fredell 2003:47; Victor 2002:173). It should, however, be pointed out that in theory there is nothing that opposes the use of a funeral pyre to serve this purpose. From a Gotlandic point of view, such a use of fire might have been regarded as an analogy to the operation of fire in the clearance of the fields. Perhaps this fire-scarred surface, whether the result of a cremation or not, should be viewed as a startingpoint for this burial ground, as the first detectable trace for us of the transformation of surroundings that eventually was the outcome of recurrent burials. For, in a longer perspective, the burial traditions of the time not only resulted in a transformation of the human body but also meant an alteration of the landscape. Since the debris of the pyre was covered with soil and stone, the graves were given a permanent character and thus the ability to serve over time. In the burial grounds, chains of events were materialized and traditions were given historical depth.

Like cultivation and the cultivated plots, the funerals and burial grounds might be regarded as arenas for the creation of bonds between people. Tove Hjørungdal has put forward public gatherings, like burials, as occasions when the young attained knowledge about the world and about their own place and the places of others in it. At these social events, people from different generations participated in a joint act, either directly or as observers. The educational gains of such an attendance may be seen as partly offering insights into how the funerals were supposed to be carried out and their ritual meanings and partly as communicating how people were expected to act on these and on other occasions (Hjørungdal 1999:88). Through participation and observation, the knowledge was spread and the tradition carried forward. 


\section{WITH CULTIVATION AS REFERENCE}

Cremation has been practised from the Stone Age to the present time, as well as in different parts of the world. Sometimes it has been the predominant way of treating the deceased, sometimes not. In some societies, cremation has been practised parallel to other types of mortuary custom (Kaliff 1997:79ff). The use of fire in burial practices is thus neither a chronologically nor a culturally definable phenomenon, but a phenomenon that can be ascribed various meanings and that is thus culturally constituted (Kaliff 1997:81ff). The same line of argument is applicable to the formation of burial grounds. To bury one's dead collectively in a specially selected place is from the historical point of view only one of many ways of treating the dead. At the same time, it does not seem to be too bold to argue that the form and meaning of this practice has probably changed over time, for example from the cemeteries of the Early Iron Age to the churchyards of today. The truly interesting question in this context is, however, how these phenomena were perceived by the Pre-Roman people.

In the last decade or so, a number of archaeologists have studied the burial customs of the Late Bronze Age and the Early Iron Age in relation to the cultivation and to the transformation of nature. Issues such as objects related to agriculture deposited in graves, but also the morphological and chorological relations of ancient remains have been treated (Ericsson 2000a, 2000b; Kaliff 1997; Varenius 1994). The source material and the theoretical perspectives have varied a bit, but the authors have often brought forward fertility and regeneration as important aspects in reaching an understanding of the tillage of the time, as well as of its mortuary practices. Alf Ericsson has stressed that burnt human bone deposited in relation to agricultural land may be explained as due to the prehistoric people on some symbolic level wishing to infuse fertility into the fields (Ericsson 2000b:35f). Björn Varenius, on the other hand, has accentuated structural similarities between cultivation and funeral traditions. He describes the cremation act as a ritualized analogy to the reproduction of "nature" and to the use of fire for agricultural purposes. "The trees and bushes of the woods, in their capacity as the "offspring" of the soil, ended their lives by being burnt and transformed into ashes. These ashes are not sterile but fertile. In them, seeds can be sown and grow to new life" (Varenius 1994:59f, my transl.). To cremate the deceased becomes, with the agricultural practice as reference, an important part of the transformation process, the very condition for the recreation of life. The aspect of fire as a life-giver was thus not limited to cultivation. Sowing, as well as the deposition of burnt bones, was hence to be regarded as a symbolical act granting new life (Varenius 1994:59ff). Tove Hjørungdal, as well as Varenius, presents the transformation of nature as central to the understanding of burial traditions, in her case in relation to the life course of the individual. As nature dies in the fall and rises again in the spring, the person during his or her lifetime is transformed from non-fertile, to fertile and (especially women) once again to non-fertile. On the basis of the theory that the ancestors might have been perceived as being responsible for abundant growth 
and prosperity, she argues that the deceased might once more have been alleged to be fertile (Hjørungdal 1999:91).

For the Gotlandic people tillage, like mortuary practices, was an activity that slowly transformed the surroundings. Field systems and burial grounds grew larger side by side, through the continuous repetition of various tasks. New plots were added to old ones in the same way as new stone settings were added to those already existing. In an earlier paper dealing with these types of remains, I have presented the material outcome of these practices as the creation of a horizontal monumentality. The purpose of this technical term is to visualize the effects on the landscape caused by these activities, while contrasting the Pre-Roman cemeteries with the more "spatially limited" monuments of the Bronze Age. The establishment of burial grounds is presented as the result of a changed perception of the landscape, partly caused by the tillage of the time (Arnberg 2004). As an example of this horizontal monumentality, we can return to Stenstugu in the central part of Kräklingbo parish. Here, two large burial grounds are lined up along a height in the landscape and immediately north-west of these are the two areas of fossilized field systems mentioned above (Fig. 2). Both types of remains are the effects of a successive growth and as time went on, both came to characterize more and more of the surroundings. Like the material effects, many of the tasks leading up to it, such as the use of fire, the grinding of seed or the crushing of bone, the spreading of seed or bone, the gathering of stones and so on, show similarities. Focusing on these similarities, experiences gained from tillage might be one of these interwoven elements constituting how the Pre-Roman people understood their burial tradition and its physical consequences.

\section{STANGA ANNEX: FURNACES AND FIELDS}

Though often hard to detect, fossilized field systems and burial grounds are, in comparison with traces of other activities, two of the remains of the Pre-Roman Iron Age that stand out most clearly in the landscape of today. Those even harder to detect, amongst them, houses and remains originating from the production of iron, may however be at least as important in the reaching of an understanding of how the people perceived their surroundings. During Pre-Roman times, iron was a material linking other phenomena together. Being made of bog ore, it was a product of the soil. In relation to agriculture, it harvested its offspring. From a mortuary perspective it returned at the end of its life to the ground. Besides this, iron, like fossilized field systems and burial grounds, was, through its coming into existence, related to the transforming fire and, like those phenomena, it was one of the factors contributing to the formation of the Gotlandic landscape.

The direct traces of iron production deriving from the Pre-Roman Iron Age are few and comprise two furnaces, one from Hallfrede in the parish of Follingbo and one from Stånga Annex in the parish of Stånga (Carlsson 1979:77; Serning 1979:175f), and a number of slag finds. The indirect traces are more common and include, amongst other things, artefacts, their find contexts and their areas of 


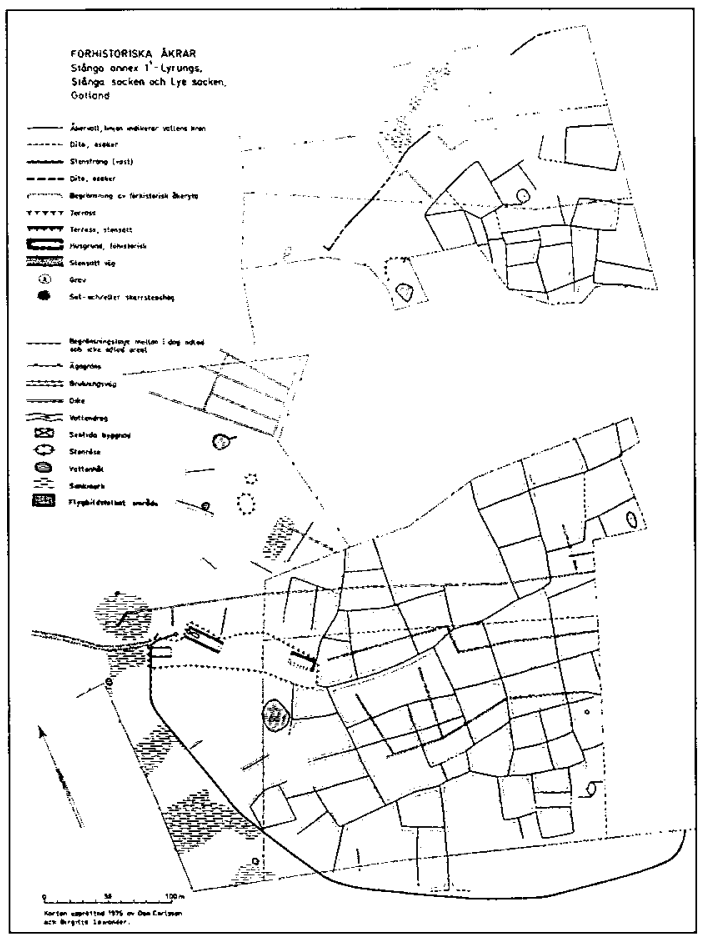

Fig. 5. Fossilized field systems at Stånga Annex I1- Lyrungs, Stainga parish and Lye parish. Map showing the field system and the habitation area (Carlsson 1976:83).

application. To the latter category, the ore-bearing bogs could also be assigned, being important factors for the understanding of the spatial organisation of iron-making. In an attempt to investigate how iron as a material and the iron production as a process might have cooperated with other activities, I now for a moment leave the parish of Kräklingbo, turning to Stånga Annex and the site of one of these furnaces.

In 1939, Sven Elvius found, in the vicinity of this locality with houses with stone foundations (Sw. stengrundshus), the remains of what he interpreted as a furnace used for the production of iron (Rydén 1979:8). Forty-four years later, a fossilized field system with earthen ridges was detected in the same area. The system was mapped out in the following year and then measured 20 hectares. At the time, the only known house with stone foundations, lay on a long and narrow plateau in the eastern part of the locality (excavations were later to show that there had originally been at least two more) (Fig. 6). Besides this, there are in the area some ten watering holes (Sw. brya) (Carlsson 1979:71f; Huttu 1996:4) (Fig. 5).

It was the correlation between the house with stone foundations and a relatively large system of fossilized fields that attracted the attention of Dan Carlsson and that led up to the first excavations of the site in 1975. The investigations, which were re-enacted in 1991, show a complex picture with remains originating from various activities separated in time (Carlsson 1975:115f; Huttu 1996:1). The visually most dominating feature is the three houses with stone foundations, which were in use during the Roman Iron Age and the Migration Period. During the Vendel Period and the Viking Age the surface inside Building 1 housed a smaller building used for different kinds of crafts (Fig. 6). (Carlsson 1979:73ff). Most interesting in this context are, however, the remains underlying the houses.

Under the remains of Building 1 appeared a $10-15-\mathrm{cm}$-thick culturally influenced layer, containing among other things ceramics, bone and charcoal. On this level were also found a layer of burnt, reddish clay and slag, and in addition, the walls of a furnace for iron production. $\mathrm{A}{ }^{14} \mathrm{C}$ sample dated the furnace to 
Fig. 6. Stainga Annex. The plateau (Carlsson 1979:73).

$255 \pm 155$ B.C.. Further down, in the transition between the culturally influenced layer and the subsoil, ard marks, dated to $135 \pm 100$ B.C., emerged. The chronological positions were perceived as somewhat odd, since the stratigraphy

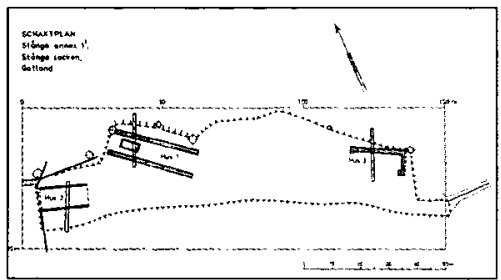
indicated that the ard marks were older than both the furnace and the slag. Dan Carlsson, however, stressed the fact that there was a risk of later charcoal being intermixed in the sample originating from the ard marks and that this was probably older than shown (Carlsson 1979:77).

The culturally influenced layer reached in under Building 2 as well. Here it had a thickness of $20-40 \mathrm{~cm}$ and contained ceramics and iron objects. In the transition to the subsoil, the remnants of a posthole, ard marks and another furnace for iron production were found (Fig.7). ${ }^{14} \mathrm{C}$ samples from the latter gave the dates A.D. $50 \pm 85$ and A.D. $90 \pm 100$, and samples alleged to originate from field clearance the date $130 \pm 110$ B.C. (Carlsson 1979:79).

On account of the plateau being used for activities on various occasions and the expressed risk of the intermixture of charcoal, these absolute datings should be used cautiously. If instead we rely on the stratigraphy of the plateau, cultivation seems to have been the first activity on the spot that left observable traces, thus preceding the production of iron. On shifting the focus to the mapped-out area as a whole, however, it is most certain from what we know of fossilized fields and their dating at other localities, that cultivation and iron production were, to a large extent, contemporaneous phenomena in the history of Stånga Annex.

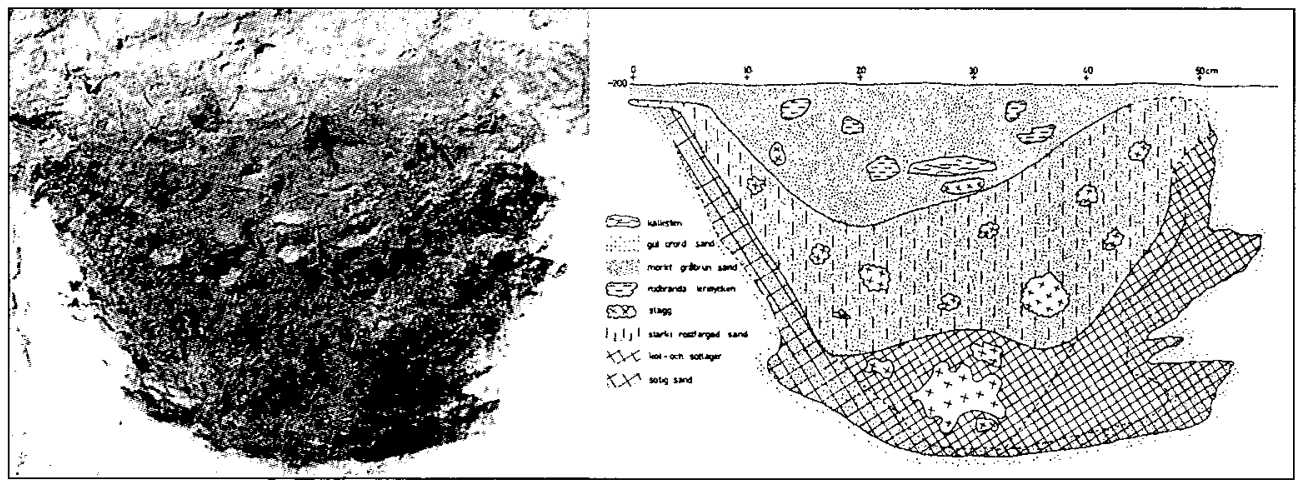

Fig. 7. Stanga Annex in the parish of Stanga. (a) Shaft 2. Photograph of the section of the furnace (Carlsson 1979:79). (b) Drawn section of the same furnace. The drawing shows the bottom of the furnace. The pit consisted of mainly three parts: (1) on the top, dark sand with pieces of burnt clay, probably the remains of the walls of the furnace; (2) under this, a layer of rust-coloured sand and large amounts of slag; (3) at the bottom, pure charcoal, soot and lots of slag. The pit was surrounded by a layer of sand mixed with soot and charcoal (Grimlund-Manneke 1979:180). 


\section{A LANDSCAPE OF IRON}

The transformation from bog ore to artefact is a procedure that often seems to have taken place over a long period of time. Examples from more recent times show that we have to assume months rather than days. The different steps may in addition, have been located in different seasons and in different parts of the landscape (see Englund 1999:108; Karlsson 2001:345f; Pettersson 1982a, 1982b). As for Gotland, there are, however, circumstances that indicate that the production of iron during the Early Iron Age can advantageously be studied in a local perspective. Finds of furnaces and slag are often located in places where bog ore has been found or in areas where theoretically it could exist (Rydén 1979:33). This is also the case of Stanga Annex. To the east, the area with the furnaces is flanked by wetlands (Fig. 5). From the moist ground in one of the shafts dug here in 1991, rust-coloured gravel and lumps of bog ore were collected (Huttu 1996:12). Besides this find, bog ore has been located in Lyrungs in the parish of Lye less than a kilometre from Stanga Annex and near Simstäde in the parish of Burs about two kilometres further away (Rydén 1979:12). The surface water in orecontaining bogs is often ruddy or covered by a greasy reddish layer (Pettersson 1982a:45). Focusing on the differing colour, it seems likely that it must in some cases have been possible to determine by ocular inspection whether a bog contained ore or not. In relation to this, names like "Rautvät" on a wetland near Simstäde and "Raudhammaren" by Stånga myr (Eng. bog) are highly interesting, since they may allude to these reddish waters (Nihlén 1932:55; Pettersson 1982a:35f; Rydén 1979: 31).

When a suitable bog had been located and the topsoil removed, the ore was collected. It was then dried and roasted and the former earth was refined and transformed (Gansum 2004:14). The furnace was built of clay. Earth was thus the material that, in combination with the flames, allowed the transformation into iron to take place (cf. Gansum \& Hansen 2002:18). Fire, in the form of the smithing hearth, also fulfilled a function in the creation of the finished product (for a more thorough presentation of the process of iron-making, see Englund 2002 and Pettersson 1982a, 1982b). As in cultivation, the practice of iron-making hence involved the recurrent use of fire and, as in cultivation, the mastery of the flames was vital. Through this controlled fire, the bog ore was transformed, a transformation that also in this case required people, communication and skill. Earth attained a new shape and hence became useful to people in another form.

By studying the material culture, we can today conclude that the immediate surroundings of the people of Stanga reached at least from the ore-containing bogs, over the cultivation areas, to the plateau where the furnaces were found. We can also conclude that on account of the natural resources, and perhaps also symbolically, these areas were symbiotically connected. The establishment of the single plot required the area to be cleared of trees, bushes and other vegetation. Parts were probably burnt on the spot, while other parts may have been saved for future building, for heating or cooking, for manufacturing of ceramics or for 
funeral pyres. As implied, the supply of wood was also one of the conditions that facilitated the transformation from ore into artefacts, artefacts that later through their fields of application on numerous levels participated in the creation of the Pre-Roman landscape. Iron was a product of the soil and in reverse it harvested the products of the soil. It thus constituted, in its various forms, integrated parts of Stånga Annex as its inhabitants knew it.

No burial grounds originating from Pre-Roman times have been excavated in the vicinity of Stånga Annex. If we instead return to Hajdeby 1:38 in the parish of Kräklingbo, all the objects that have survived the pyre and the ravages of time are of metal. Some of the objects here entombed had started their course as formless lumps of bog ore collected from the moist soil. By being exposed to fire in several steps, these were eventually altered and took on novel shapes as imperishable artefacts. At the end of their lives, this time accompanying the deceased, they were once again subjected to the flames and then finally returned to the ground. The elements of earth and fire were hence integrated and recurrent parts of the life-cycle of the buried objects, as well as of the burial practice on the whole. As shown, the same elements can be used to describe the agricultural tradition of the time. In the hands of skilled people, earth and fire participated in the alteration of natural resources and in the creation of a material culture.

\section{TO SUM UP}

This paper has studied to the destroying, transforming and creating characters of fire in relation to the Pre-Roman Iron Age on Gotland. It has also discussed the material expressions of the time and the activities leading up to them. In a shorter period of time, these activities induced a transformation to the little, i.e. in relation to the single deceased, the single plot and the single object. In a longer perspective, however, these activities also affected large parts of the surroundings. By recurrently being exposed to fire, the landscape was created and controlled. The people made it into their own.

As they are visible in the landscape today, both fossilized field systems and burial grounds are the result of a chronologically long-drawn-out process constituted by repetitive events. It is probable that these events in a contemporary perspective involved a series of people. It is certain that they did when the whole period is taken into consideration. As material expression the phenomena bear witness to the fact that the tasks, if not completely unchanged, were carried out in a similar way during the centuries. The activities brought people from different generations together and connected them in a materially established tradition. Being involved in different tasks, the Pre-Roman people obtained a role in relation to their surroundings that could be oriented towards the contemporary society but that through its material expressions also reached outside the individual's lifetime.

English revised by Neil Tomkinson. 


\section{REFERENCES}

Arnberg, A. 2004. Horisontell monumentalitet. Några tankar kring det förromerska landskapet på Gotland. Aktuell Arkeologi VIII. Stockholm. Pp. 47-58.

Bradley, R. 2002. The Past in Prehistoric Societies. London \& New York.

Carlsson, D. 1975. Det förhistoriska jordbruket. Undersökningar inom Stånga annex i Stånga. Gotländskt Arkiv. Pp. 115-116.

- 1976. Ett vendel-vikingatida verkstadshus på Gotland. Fornvännen 71. Pp. 82-88.

- 1979. Kulturlandskapets utveckling på Gotland. En studie av jordbruks- och bebyggelseförändringar under järnåldern. Kulturgeografiska institutionen, Stockholms universitet. Meddelande B 49. Visby. Diss.

- 1992. Storbranden i Kräklingbo, Gotland. Inventering av skadade fornlämningar. Förslag till åtgärder. IKOS. Rapport 1992:8.

- 1993. Nyupptäckta fornlämningar i brandens spår. Gotländskt Arkiv. Pp. 17-30.

Eliason, S. 1993. Torsburgen ett år efter branden - födelse och pånyttfödelse. Gotländskt Arkiv. Pp. 11-16.

Englund, L-E. 1999. Havandeskap och järnframställning. In: Caesar, C., Gustin, I., Iregren, E., Peterson, B., Rudebeck, E. \& Räf, E. \& Ströbeck, L. (Eds). Han, hon, den, det. Att integrera genus och kön i arkeologi. Lund. Pp. 107-114.

- 2002. Blästbruk. Myrjärnshanteringens förändringar i ett långtidsperspektiv. Jernkontorets Bergshistoriska Skriftserie nr 40. Stockholm. Diss.

Ericsson, A. 2000a. Odlingslandskapets arkeologi. Vetenskaplig verksamhetsplan för UV Öst. Arkeologiskt program 2000-2002. Rapport UV Öst 2000:21. Linköping. Pp. 18-32.

- 2000b. Forntida jordbruk och begravningsriter i Hugelsta. Arkeologisk förundersökning och undersökning. E20, Södermanland, Eskilstuna stadsområde, Grönsta 2:20, RÄ̈ 215 och 298. UV Mitt, rapport 2000:46. Stockholm.

Fredell, $\AA$. 2003. Bronze Age Imagery. Through Water and Fire. Current Swedish Archaeology, Vol 11. Pp. 45-63.

Gansum, T. \& Hansen, J. 2002. Fra jern til stål-mytologiske og rituelle aspekter i teknologiske processer. Borre.

Gansum, T. 2004. The Archaeology of the Earth. Current Swedish Archaeology, Vol 12. Pp. 7-21.

Gheorghiu, D. 2002. Towards Pyroarchaeology. In: Gheorghiu, D. (Ed). Fire in Archaeology. Papers from a session held at the European Association of Archaelogists Sixth Annual Meeting in Lissabon 2000. BAR International Series 1089. Oxford. Pp. 1-5.

Gren, L. 1995. Bronsålderns hackerörsområden och användningen av eld. In: Larsson, B. (Ed). Svedjebruk och röjningsbränning $i$ Norden - terminologi, datering, metoder. Skrifter som skogs- och lantbrukshistoria 7. Stockholm. Pp. 90-94.

Grimlund-Manneke, G. 1979. Järnmalm på Gotland? Arkeologi på Gotland. Gotlandica 14. Visby. Pp 179180.

Hjørungdal, T. 1999. Kremering och dekonstruktion/rekonstruktion av identitet. Vilka är representerade $\mathrm{i}$ brandgravar med Vestlandkittel? In: Caesar, C., Gustin, I., Iregren, E., Peterson, B., Rudebeck, E. \& Räf, E. \& Ströbeck, L. (Eds). Han, hon, den, det. Att integrera genus och kön i arkeologi. Lund. Pp. 8195.

Huttu, John, 1996. Järn och Korn. Undersökning med målsättningen att förklara bakgrunden till järnåldersboplatsen Stånga annex etablering, samt göra ett rekonstruktionsförsök av denna forntidsmiljö. Uppsats för påbyggnadskurs vid Stockholms universitet/Högskolan på Gotland, Ht 1996.

Ingold, Tim. 2000. The Perception of the Environment. Essays on livelihood, dwelling and skill. London \& New York.

Johansson, S. 1993. Fossil åkermark i Kräklingbo och Alskogs socknar, Gotland. En jämförande analys av två fossila odlingssystem. Uppsats för påbyggnadskurs i arkeologi vid Stockholms Universitet, VT 1993. Stockholm.

Kaliff, A. 1997. Grav och kultplats. Eskatologiska föreställningar under yngre bronsålder och äldre järnålder $i$ Östergötland. Aun 24. Uppsala. Diss. 
Karlsson, C. 2001. Möre, järnet och människan. In: Magnusson, G. \& Selling, S. (Ed). Möre: historien om ett småland. E22-projektet. Kalmar. Pp 345-366.

Lang, V. 1994. Celtic and Baltic Fields in North Estonia. Fossil Field Systems of the Late Bronze Age and the Pre-Roman Iron Age at Saha-Loo and Proosa. Acta Archaeologica, vol. 65 (1994). Copenhagen. Pp. 203-219.

Lindquist, S-O. 1974. The Developement of the Agrarian Landscape on Gotland during the Early Iron Age. Norwegian Archaeological Review, vol. 7. Pp. 6-32.

- 1993. Branden i Kräklingbo - några tankar kring en flygbild. Gotländskt Arkiv. Pp. 7-10.

Manneke, Peter, 1974. Aerial Photography of "Celtic Fields" on Gotland. Norwegian Archaeological Review. Pp. 32-38.

Myrdal, J. 1995. Inledning. In: Larsson, B. (Ed). Svedjebruk och röjningsbränning i Norden-terminologi, datering, metoder. Skrifter om skogs- och lantbrukshistoria 7. Stockholm. Pp. 5-13.

Nihlén, J. 1932. Studier rörande äldre svensk järntillverkning med särskild hänsyn till Smäland. Järnkontorets bergshistoriska skriftserie nr. 2. Stockholm.

Nylén, E. 1955. Die jüngere vorrömische Eisenzeit Gotlands. Funde, Chronologie, Formenkunde. Uppsala. Diss.

- 1958a. Gotländska gravformer och deras betydelse för kronologin. Tor, vol. 4. Uppsala. Pp. 64-86.

- 1958b. Gotlands forntid i bilder. Yngre förromersk järnålder. Uppsala.

Pettersson, T. J-E. 1982a. Myrmalmen och dess rostning. In: Björklund, S. (Ed). Lima och Transtrand. Ur två socknars historia. Myrjärn och Smide 1. Malung. Pp. 35-68.

- 1982b. Blästan och blåsningen. In: Björklund, S. (Ed). Lima och Transtrand. Ur två socknars historia. Myrjärn och Smide 1. Malung. Pp. 69-121.

Rydén, H. 1979. Förhistorisk järnhantering på Gotland. Malmer, slagger, ugnar, ämnesjärn. Inventering, kartering, utvärdering. 60-poängsuppsats vid institutionen för arkeologi, särskilt nordeuropeisk, vid Stockholms universitet. Ht 1979. Stockholm.

Serning, I. 1979. Grop-schaktugnen från Hallfrede i Follingbo. Arkeologi på Gotland. Gotlandica 14. Visby. Pp. 173-178.

Spek, T, Groenman-van Waateringe, W, Kooistra, M \& Bakker, L. 2003. Formation and Land-Use History of Celtic Fields in North-West Europe - An Interdiciplinary Case Study at Zeijen, the Netherlands. European Journal of Archaeology. Vol. 6(2). Pp. 141-173.

Thomas, J. 1996. Time, Culture and Identity. An Interpretative Archaeology. London \& New York.

Varenius, B. 1994. Monument och samhällelig reproduktion. Äldre järnålder i norra Småland. Kulturmiljövård 5/1994. Pp. 56-63.

Victor, H. 2002. Med graven som granne. Om bronsålderns kulthus. Aun 30. Uppsala. Diss.

Windelhed, B. 1984a. Tidiga gotländska produktionsenheter och deras markanvändning. Erfarenheter från en lokal studie av förändringar av kulturlandskap från förhistorisk tid till tidig medeltid vid Vinarve $\mathrm{i}$ Rone socken på Gotland. In: Liedgren, L. \& Widgren, M. (Eds). Gård och kulturlandskap under järnåldern./svensk-norskt seminarium i Hudiksvall 18-20 augusti 1983. Kulturgeografiskt seminarium, (19)84:2. Stockholm. Pp. 173-195

- 1984b. "Celtic Fields" and Prehistoric Agrarian Landscapes. Approach, Methods and Results from a Human Geographical Study of Reasons for the Developement of the Agrarian Society at Vinarve in Rone Parish on Gotland, Sweden. In: Kristiansen, K. (Ed). Settement and Economy in later Scandinavian Prehistory. BAR Int. Ser. 211. Oxford. Pp. 85-110

Zerpe, L. 1999. Hajdeby 1:38, 1:39 m fl. RÄ̈ 171, $218 \mathrm{~m} f l$, Kräklingbo socken, Gotland. Undersökning av gravfält. Förromersk järnålder: Aterställande av gravar och röjningsrösen. Odaterade. UV Visby Rapport 1999:15. Visby.

Östergren, M. 1992. Efter branden vid Torsburgen. Kulturmiljövård, nr 5/1992. Pp. 44-47. 
